\title{
A comprehensive evaluation of utilization potential of semiterrestrial isopods, Ligia exotica in China: a new aquatic feed?
}

\section{Lele Xu ( $\square$ xulees@foxmail.com )}

Lingnan Normal University https://orcid.org/0000-0002-6591-8571

\section{Yongqin Li}

Lingnan Normal University

Yao Liu

Lingnan Normal University

\section{Xiang Jiang}

Lingnan Normal University

\section{Yulin Sun}

Lingnan Normal University

Haifeng Mi

Tongwei Group. Co.,Ltd

Haiyong Zhao

Beijing Normal University - Zhuhai Campus

\section{Daohai Chen}

Lingnan Normal University

\section{Liyun Wang}

Lingnan Normal University

\section{Research}

Keywords: Ligia exotica, nutritional analysis, distribution, aquaculture

Posted Date: September 1st, 2020

DOI: https://doi.org/10.21203/rs.3.rs-64796/v1

License: (9) (1) This work is licensed under a Creative Commons Attribution 4.0 International License. Read Full License 


\section{Abstract}

Background: The semiterrestrial isopod, Ligia exotica represents one of the oldest documented species introductions of marine organisms and is known as an intermediate form between marine and strictly terrestrial isopods. In order to explore the practical value for food \& feed of Ligia, this study focused on growth rate under laboratory rearing conditions and detailed analysis of the overall nutrient content of the species in comparison to two other aquatic food media (krill and fish meal).

Results: Evaluation of the growth rate of juveniles suggests it is a relatively fast-growing species of the Ligiidae family. The essential amino acids content Ligia meal is the lowest but the proportion of flavor amino acids was higher. In particular, the content of taurine was much higher. Amino acid score and chemical score show that the most restricted amino acids of isopod meal are methionine and cysteine. The extremely unbalanced amino acid composition may affect the absorption and utilization by consumers. In terms of fatty acids, the total polyunsaturated fatty acids in isopod is very low. A total of 12 vitamins were examined. The $\mathrm{VK}_{1}, \mathrm{VE}, \mathrm{VB}_{2}, \mathrm{VB}_{3}, \mathrm{VB}_{5}$ content of isopod meal were significantly higher than those of krill meal and fish meal. Similarly, most of the 11 mineral elements are the highest in isopod meal.

Conclusions: Ligia offers potential as an alternative natural food source especially in aquaculture given the growth rate under culture and the overall nutrient content. But Ligia collected in most of the field would be deemed unfit for human consumption because of the relatively low nutritional value and heavy metal content exceeding the provided standard. Ligia isopods offer some potential to become a crustacean model animal for commercial aquaculture crustaceans, further study is warranted to elucidate its biological characteristics.

\section{Background}

Ligia is a genus of isopods (Isopoda; Crustacea), which is commonly known as rock lice or sea slaters based on its appearance. Most Ligia species live on tidal zone cliffs and rocky beaches, as well as dams, ports and docks and tolerate a wide range of temperatures and salinity. They are distributed across almost the entire coastline of China and have naturally high biomass. Coastal Ligia exhibits a mixture of terrestrial and marine characteristics, drying out easily, needing moist air and proximity to water. Although they have gills and can exchange gas under water, they only do so when escaping terrestrial predators or being dislodged by wave action. They do not move swiftly in the water and are open to marine predation. They are well adapted to rocky surfaces but avoid exposed sand, which opens them to terrestrial predation and desiccation (Hurtado et al.2010). The fertilized eggs of L. exotica develop into juveniles in the brood pouch (oöstegites) of females until they can live independently. It takes about 5wk from egg deposition to release (Carefoot, 1973). Further details of their biology, including types, habitats, reproduction, food, growth, physiology et al can be found in an academic website A Snail's Odyssey (Carefoot, 2020), and Taiti et al. 2003; Renate Eberl, 2012.

Ligia isopods are omnivorous detrivores and feed by chewing on organic debris on the shore. Ligia isopods themselves are often used as bait by fishermen and they are the primary prey for mangrove crabs, fish, birds, and lizards (Grismer, 1994) and even small mammals (Garciahernandez. et al.2015). Ligia are considered to play an active role in nutrient recycling and energy flow in the near shore environment and in supporting the biodiversity of the coastal zone (Huang et al. 2015). 
Our preliminarily study has confirmed that Ligia exotica can provide a high-quality natural diet for cultured cuttlefish Sepia pharaonis (Xu et al. 2018). Ligia isopods are also utilized in traditional Chinese medicine for the treatment of muscle injury, swelling and pain, or to overcome malnutrition in children (Sun et al. 2015). Extracts from Ligia exotica were proven to have obvious proliferation inhibitory effects on a range of biochemical and cellular functions such as cervical cancer cells HeLa, stomach cancer cell SGC-7901 and NCl60 human tumor cell in vitro and have an inhibitory effect on mouse sarcoma S180-induced transplantable cancers by intraperitoneal injection in tumors over 7d (Bian et al. 2007). A novel nucleoside, elucidated as 3'-O(a-D-glucosyl) inosine, had been isolated from Ligia exotica but no bioactivity identified (Seong et al. 2000).

As far as we are aware, there is no published report on the nutritional analysis of Ligia isopods although there is evidence of potential nutritional as well as medicinal value. To explore this potential value further we established a 70-day culture experiment on juveniles of Ligia to evaluate their growth performance and compared the nutritional content of Ligia exotica meal with two other regular used marine feed sources, white fish meal and Antarctic krill (Euphausia superba) meal. The objectives included whether Ligia can be artificially cultured on a large scale and to document their growth rate and how well the nutritional value compared with the reference feed sources. It is hoped that the approach adopted here can provide information on this potential as a feed source within animal culture as well as contributing to increasing our understanding of basic crustacean physiology.

\section{Materials And Methods}

\section{Growth rate determination of juveniles Ligia exotica}

Ligia exotica (Chen et al. 1987. Figure.1) were collected at the embankment of Tiaoshun Island in Zhanjiang City, Guangdong Province, China (N21 $\left.{ }^{\circ} 28, \mathrm{E} 110^{\circ} 39^{\prime}\right)$, and were cultured in a $40 \mathrm{~cm} \times 20 \mathrm{~cm} \times 30 \mathrm{~cm}$ aquarium, with oyster shells stacked on the right side and a plastic baffle with small holes through which seawater can pass was fixed to the left $10 \mathrm{~cm}$ of the aquarium. Sea water reached half the height of the oyster stack and a filter pump was installed. Daily feeding of Ligia exotica was with tilapia fish pellet feed placed on dry oyster shells.

\section{Isolated Culture Of Gravid Females}

When gravid females were observed, especially where fertilized eggs in the marsupium were found to change color from orange to black, they were immediately isolated into a plastic box with a layer of cotton covered with a layer of gauze on the bottom. A piece of paper was placed on the gauze and thoroughly wetted with clean seawater. Tilapia pellet feed was spread on the paper as a food source. The cotton, gauze and seawater were changed every two days.

\section{Culture Of Juveniles}

When developed to a certain extent, the 50-60 juveniles would crawl out from the brooding female. The time of birth was recorded, and the mothers removed from the plastic box to avoid cannibalism. Juveniles were divided into groups of 10 and cultured in a constant temperature incubator at $28^{\circ} \mathrm{C}$. The culture conditions are described above. 


\section{Sampling}

Each group of juveniles were sampled every 5 days and the culture experiment lasted for a total of 70 days, providing 15 temporal samples. After being frozen at $-20^{\circ} \mathrm{C}$, they were placed at room temperature for 20 minutes to volatilize the water on the body surface and were weighed with a high-precision electronic balance. The replicate groups of juveniles were weighed on the same days after hatching from different mothers.

\section{Analysis of nutritional components of Ligia exotica and comparative substrates}

\section{Analysis Method}

The frozen Ligia exotica contained individuals caught in the field, were subsequently dried at $75^{\circ} \mathrm{C}$ for one day in an oven, ground into powder and stored at $-20^{\circ} \mathrm{C}$ until analysis.

Two readily available aquatic food substrates were used for comparative purposes. Antarctic krill (Euphausia superba) meal was purchased from China National Fisheries Corporation. It was rapidly cooked at $80 \sim 95^{\circ} \mathrm{C}$ for $20 \sim 25 \mathrm{~min}$, dehydrated and dried on board when caught at sea and transported to the laboratory to be stored at $-20^{\circ} \mathrm{C}$.

Fishmeal was white fish meal (degreased) imported from Russia, which was mainly composed of the pacific cod Gadus macrocephalus. When delivered to the laboratory, the samples were divided into several bags, stored at $-20{ }^{\circ} \mathrm{C}$ and sampled at random during the experiment.

A range of nutrient components were analyzed from Ligia and the comparative substrates as described in Table 1. 
Table 1

Nutritional items and their determination methods

\begin{tabular}{|c|c|c|c|}
\hline \multirow{2}{*}{$\begin{array}{l}\text { Nutrient components } \\
\text { Moisture }\end{array}$} & \multicolumn{2}{|c|}{$\begin{array}{l}\text { Code and name of Chinese national } \\
\text { determination standard }\end{array}$} & \multirow{2}{*}{$\begin{array}{l}\text { Brief description of methods } \\
\text { and equipment }\end{array}$} \\
\hline & $\begin{array}{l}\text { GB 5009.3- } \\
2016\end{array}$ & $\begin{array}{l}\text { Determination of moisture in } \\
\text { feedstuffs }\end{array}$ & \\
\hline Crude protein & $\begin{array}{l}\text { GB 5009.5- } \\
2016\end{array}$ & $\begin{array}{l}\text { Determination of crude protein } \\
\text { in feeds }\end{array}$ & Kjeldahl method \\
\hline Crude ash & $\begin{array}{l}\text { GB } 5009.4- \\
2016\end{array}$ & $\begin{array}{l}\text { Animal feeding stuff- } \\
\text { Determination of Crude ash }\end{array}$ & $550^{\circ} \mathrm{Cin}$ muffle furnace \\
\hline Crude fat & $\begin{array}{l}\text { GB 5009.6- } \\
2016\end{array}$ & $\begin{array}{l}\text { Determination of Crude fat in } \\
\text { feeds }\end{array}$ & Soxhlet extraction \\
\hline Taurine & $\begin{array}{l}\text { GB } \\
5009.169 .2016\end{array}$ & $\begin{array}{l}\text { Determination of taurine in } \\
\text { food }\end{array}$ & $\begin{array}{l}\text { neighbor grows responds } \\
\text { with o-Phthalaldehyde }\end{array}$ \\
\hline Amino acids & $\begin{array}{l}\text { GB } 5009.124- \\
2016\end{array}$ & $\begin{array}{l}\text { Determination of amino acids } \\
\text { in foods }\end{array}$ & amino acid analyzer \\
\hline Cystine & $\begin{array}{l}\text { GB/T } 18246- \\
2000\end{array}$ & $\begin{array}{l}\text { Determination of amino acids } \\
\text { in feeds }\end{array}$ & oxidation hydrolysis \\
\hline Tryptophan & $\begin{array}{l}\text { GB/T } 18246- \\
2000\end{array}$ & $\begin{array}{l}\text { Determination of amino acids } \\
\text { in feeds }\end{array}$ & Alkali hydrolysis, RP-HPLC \\
\hline $\begin{array}{l}\text { Vitamin A \& Vitamin } \\
\text { E \& Vitamin } D_{3}\end{array}$ & $\begin{array}{l}\text { GB } 5009.82- \\
2016\end{array}$ & $\begin{array}{l}\text { Determination of vitamin A, D, } \\
\text { E in food }\end{array}$ & RP-HPLC \\
\hline Vitamin $B_{1}$ & $\begin{array}{l}\text { GB 5009.84- } \\
2016\end{array}$ & $\begin{array}{l}\text { Determination of vitamin } B_{1} \text { in } \\
\text { food }\end{array}$ & HPLC \\
\hline Vitamin $B_{2}$ & $\begin{array}{l}\text { GB } 5009.85- \\
2016\end{array}$ & $\begin{array}{l}\text { Determination of vitamin } B_{1} \text { in } \\
\text { food }\end{array}$ & HPLC \\
\hline Vitamin $B_{3}$ & $\begin{array}{l}\text { GB } 5009.89- \\
2016\end{array}$ & $\begin{array}{l}\text { Determination of niacin in } \\
\text { food }\end{array}$ & HPLC \\
\hline Vitamin $\mathrm{B}_{5}$ & $\begin{array}{l}\text { GB } 5009.210- \\
2016\end{array}$ & $\begin{array}{l}\text { Determination of pantothenic } \\
\text { acid in food }\end{array}$ & HPLC \\
\hline Vitamin $\mathrm{B}_{6}$ & $\begin{array}{l}\text { GB/T } 14702- \\
2018\end{array}$ & $\begin{array}{l}\text { Determination of vitamin } \mathrm{B}_{6} \text { in } \\
\text { premix }\end{array}$ & HPLC \\
\hline Vitamin $B_{12}$ & $\begin{array}{l}\text { GB/T } 17819- \\
2017\end{array}$ & $\begin{array}{l}\text { Determination of vitamin } B_{12} \\
\text { in additive premix }\end{array}$ & HPLC \\
\hline Vitamin C & $\begin{array}{l}\text { GB } 5009.86- \\
2016\end{array}$ & $\begin{array}{l}\text { Determination of ascorbic } \\
\text { acid in food }\end{array}$ & HPLC \\
\hline Vitamin K1 & $\begin{array}{l}\text { GB } 5009.158- \\
2016\end{array}$ & $\begin{array}{l}\text { Determination of vitamin K1 } \\
\text { in food }\end{array}$ & $\begin{array}{l}\text { HPLC plus fluorescence } \\
\text { detection }\end{array}$ \\
\hline Folic acid & $\begin{array}{l}\text { GB/T } 17813- \\
2018\end{array}$ & $\begin{array}{l}\text { Determination of folic acid in } \\
\text { premix }\end{array}$ & HPLC \\
\hline
\end{tabular}




\begin{tabular}{|c|c|c|c|}
\hline \multirow{2}{*}{$\begin{array}{l}\text { Nutrient components } \\
\text { Nicotinic acid }\end{array}$} & \multicolumn{2}{|c|}{$\begin{array}{l}\text { Code and name of Chinese national } \\
\text { determination standard }\end{array}$} & \multirow{2}{*}{$\begin{array}{l}\text { Brief description of methods } \\
\text { and equipment }\end{array}$} \\
\hline & $\begin{array}{l}\text { GB } 5009.89- \\
2016\end{array}$ & $\begin{array}{l}\text { Determination of niacin and } \\
\text { nicotine in food }\end{array}$ & \\
\hline Pantothenic acid & $\begin{array}{l}\text { GB } 5009.210- \\
2016\end{array}$ & $\begin{array}{l}\text { Determination of pantothenic } \\
\text { acid in food }\end{array}$ & HPLC \\
\hline Potassium \& Sodium & $\begin{array}{l}\text { GB } 5009.91- \\
2017\end{array}$ & $\begin{array}{l}\text { Determination of potassium } \\
\text { and sodium in food }\end{array}$ & FAAS \\
\hline Magnesium & $\begin{array}{l}\text { GB } 5009.241- \\
2017\end{array}$ & $\begin{array}{l}\text { Determination of Magnesium } \\
\text { and sodium in food }\end{array}$ & FAAS \\
\hline Calcium & $\begin{array}{l}\text { GB } 5009.92- \\
2016\end{array}$ & $\begin{array}{l}\text { Determination of calcium in } \\
\text { food }\end{array}$ & FAAS \\
\hline Copper & $\begin{array}{l}\text { GB } 5009.13- \\
2017\end{array}$ & $\begin{array}{l}\text { Determination of copper in } \\
\text { food }\end{array}$ & $\begin{array}{l}\text { graphite furnace atomic } \\
\text { absorption }\end{array}$ \\
\hline Chromium & $\begin{array}{l}\text { GB 5009.268- } \\
2016\end{array}$ & $\begin{array}{l}\text { Determination of multiple } \\
\text { elements in Food }\end{array}$ & ICP-MS \\
\hline Ferrum & $\begin{array}{l}\text { GB } 5009.90- \\
2016\end{array}$ & $\begin{array}{l}\text { Determination of multiple } \\
\text { elements in Food }\end{array}$ & $\begin{array}{l}\text { Flame atomic absorption } \\
\text { spectrometry (FAAS) }\end{array}$ \\
\hline Zinc & $\begin{array}{l}\text { GB } 5009.14- \\
2017\end{array}$ & Determination of zinc in food & FAAS \\
\hline Manganese & $\begin{array}{l}\text { GB/T } 13885- \\
2017\end{array}$ & $\begin{array}{l}\text { Determination of the content } \\
\text { of manganese in feed }\end{array}$ & $\begin{array}{l}\text { Atomic absorption } \\
\text { spectrometry }\end{array}$ \\
\hline Total phosphorus & $\begin{array}{l}\text { GB/T } 6437- \\
2018\end{array}$ & $\begin{array}{l}\text { Determination of phosphorus } \\
\text { in feeds }\end{array}$ & spectrometry \\
\hline Cholesterol & $\begin{array}{l}\text { GB 5009.128- } \\
2016\end{array}$ & $\begin{array}{l}\text { Determination of cholesterol } \\
\text { in food }\end{array}$ & HPLC \\
\hline
\end{tabular}

\section{Evaluation Of Nutritional Quality Of Amino Acids}

Based on the amino acid scoring standard model recommended by FAO \& WHO (1985) and the amino acid model using egg protein as an ideal protein reference, the Amino Acid Score (AAS), Chemical Score (CS) and Essential Amino Acid Index (EAAI) from eight essential amino acids for humans were calculated from the following formulae (Pellett \& Yong, 1980). The higher the scores and indices that the substrates received, the more similarity they are with the ideal protein model, and the better the protein quality for human consumption. 

$\mathrm{AAS}=\frac{a a}{A A \text { FAO\& WHO }}$
$\mathrm{CS}=\frac{a a}{A A \mathrm{Egg}}$
$\mathrm{EAAI}=\sqrt[n]{\frac{100 A}{A E} \times \frac{100 B}{B E} \times \frac{100 C}{C E} \times \ldots \times \frac{100 I}{I E}}$

where $a a$ is the amino acid content of the sample (\%); $A A_{\text {FAO\&WHO }}$ is the content of the same amino acid recommended by FAO \& WHO () (shown in Table 5); $A A_{\text {egg }}$ is the content of the same amino acid in whole egg protein ( ()$; n$ is the number of essential amino acids compared $(n=9)$. A, B, C, ..; I is the content of essential amino acid of sample protein $(\mathrm{mg} / \mathrm{g} \mathrm{N}), \mathrm{AE}, \mathrm{BE}, \mathrm{CE}, \ldots ; \mathrm{IE}$ is the content of essential amino acid of whole egg protein $(\mathrm{mg} / \mathrm{g} \mathrm{N})$. 
Table 5

Comparative analysis of Amino Acid Score (AAS), Chemical Score (CS) and Essential Amino Acid Index (EAAI) of antarctic krill meal and isopod meal

\begin{tabular}{|c|c|c|c|c|c|c|}
\hline \multicolumn{2}{|c|}{ Amino acids } & \multirow{2}{*}{$\begin{array}{l}\text { FAO evaluation } \\
\text { standard(mg/gN) } \\
250\end{array}$} & \multirow[t]{2}{*}{$\begin{array}{l}\text { Egg protein } \\
\text { standard }(\mathrm{mg} / \mathrm{gN})\end{array}$} & \multirow{2}{*}{$\begin{array}{l}\text { Score of } \\
\text { isopod meal } \\
0.30 \pm 0.01^{a}\end{array}$} & \multirow{2}{*}{$\begin{array}{l}\text { Score of } \\
\text { krill meal } \\
0.60 \pm 0.01 \\
b\end{array}$} & \multirow{2}{*}{$\begin{array}{l}\text { Score of } \\
\text { fish meal } \\
0.73 \pm 0.03 \\
c\end{array}$} \\
\hline AAS & Ile & & & & & \\
\hline & Leu & 440 & & $0.61 \pm 0.11^{b}$ & $\begin{array}{l}0.55 \pm 0.06 \\
a\end{array}$ & $\begin{array}{l}0.78 \pm 0.05 \\
c\end{array}$ \\
\hline & Lys & 340 & & $0.62 \pm 0.04^{a}$ & $\begin{array}{l}0.68 \pm 0.02 \\
b\end{array}$ & $\begin{array}{l}0.99 \pm 0.07 \\
c\end{array}$ \\
\hline & Thr & 250 & & $0.47 \pm 0.05^{a}$ & $\begin{array}{l}0.48 \pm 0.05 \\
b\end{array}$ & $\begin{array}{l}0.75 \pm 0.08 \\
c\end{array}$ \\
\hline & Val & 310 & & $0.79 \pm 0.06^{c}$ & $\begin{array}{l}0.48 \pm 0.06 \\
a\end{array}$ & $\begin{array}{l}0.69 \pm 0.04 \\
b\end{array}$ \\
\hline & Trp & 60 & & $0.64 \pm 0.1^{a}$ & $\begin{array}{l}0.92 \pm 0.04 \\
b\end{array}$ & $0.65 \pm 0.1^{a}$ \\
\hline & $\begin{array}{l}\text { Met } \\
+ \text { Cys }\end{array}$ & 220 & & $0.18 \pm 0.01^{a}$ & $\begin{array}{l}0.80 \pm 0.01 \\
b\end{array}$ & $\begin{array}{l}0.88 \pm 0.02 \\
c\end{array}$ \\
\hline & $\begin{array}{l}\text { Phe } \\
+ \text { Tyr }\end{array}$ & 380 & & $0.59 \pm 0.05^{a}$ & $\begin{array}{l}0.67 \pm 0.01 \\
b\end{array}$ & $\begin{array}{l}0.86 \pm 0.00 \\
c\end{array}$ \\
\hline \multirow[t]{8}{*}{ CS } & Ile & & 331 & $0.22 \pm 0.03^{a}$ & $\begin{array}{l}0.46 \pm 0.03 \\
b\end{array}$ & $\begin{array}{l}0.55 \pm 0.07 \\
c\end{array}$ \\
\hline & Leu & & 534 & $0.50 \pm 0.02^{b}$ & $\begin{array}{l}0.46 \pm 0.01 \\
a\end{array}$ & $\begin{array}{l}0.64 \pm 0.03 \\
c\end{array}$ \\
\hline & Lys & & 441 & $0.48 \pm 0.02^{a}$ & $\begin{array}{l}0.53 \pm 0.01 \\
b\end{array}$ & $\begin{array}{l}0.76 \pm 0.05 \\
c\end{array}$ \\
\hline & Thr & & 292 & $0.40 \pm 0.04^{a}$ & $\begin{array}{l}0.41 \pm 0.04 \\
b\end{array}$ & $\begin{array}{l}0.64 \pm 0.06 \\
c\end{array}$ \\
\hline & Val & & 410 & $0.59 \pm 0.05^{c}$ & $\begin{array}{l}0.36 \pm 0.04 \\
a\end{array}$ & $\begin{array}{l}0.53 \pm 0.03 \\
b\end{array}$ \\
\hline & Trp & & 106 & $0.36 \pm 0.06^{a}$ & $\begin{array}{l}0.52 \pm 0.02 \\
b\end{array}$ & $\begin{array}{l}0.37 \pm 0.05 \\
a\end{array}$ \\
\hline & $\begin{array}{l}\text { Met } \\
+ \text { Cys }\end{array}$ & & 386 & $0.10 \pm 0.06^{a}$ & $\begin{array}{l}0.45 \pm 0.06 \\
b\end{array}$ & $\begin{array}{l}0.50 \pm 0.01 \\
c\end{array}$ \\
\hline & $\begin{array}{l}\text { Phe } \\
+ \text { Tyr }\end{array}$ & & 565 & $0.40 \pm 0.03^{a}$ & $\begin{array}{l}0.45 \pm 0.08 \\
b\end{array}$ & $\begin{array}{l}0.58 \pm 0.02 \\
c\end{array}$ \\
\hline
\end{tabular}

Numerical values marked with the letter ${ }^{\mathrm{a}, \mathrm{b}}$ or $^{\mathrm{c}}$ are statistically significantly different. 


\begin{tabular}{|llllll|}
\hline Amino acids & $\begin{array}{l}\text { FAO evaluation } \\
\text { standard(mg/gN) }\end{array}$ & $\begin{array}{l}\text { Egg protein } \\
\text { standard(mg/gN) }\end{array}$ & $\begin{array}{l}\text { Score of } \\
\text { isopod meal }\end{array}$ & $\begin{array}{l}\text { Score of } \\
\text { krill meal }\end{array}$ & $\begin{array}{l}\text { Score of } \\
\text { fish meal }\end{array}$ \\
\hline EAAl & & $34.13 \pm 0.48^{\mathrm{a}}$ & $\begin{array}{l}45.16 \pm \\
0.64^{\mathrm{b}}\end{array}$ & $\begin{array}{l}55.93 \pm \\
0.57^{\mathrm{c}}\end{array}$ \\
\hline \multicolumn{2}{|l}{ Numerical values marked with the letter ${ }^{\mathrm{a}, \mathrm{b}}$ or $^{\mathrm{c}}$ are statistically significantly different. } \\
\hline
\end{tabular}

\section{Statistic Analysis}

Following the Chinese national determination standard method to analyze the nutritional components of substrates, the analysis of each samples was repeated three times by the same tester to obtain data for statistical analysis. When conducting the fatty acid and vitamin content analysis, the concentration of some parameters that were too low to be detected (ND) and were considered zero with no statistical analysis undertaken. Before analyzing all the data statistically, their normality was tested by Shapiro-Wilk test method in SPSS 24.0 software. It indicated that all the original data follow the normal distribution.

Levene's test was adopted to deal with nutritional parameters with specific values for Analysis of Variance (ANOVA, two tailed) in three raw materials (isopod meal, antarctic krill meal and fishmeal). If the data followed the assumption of homogeneity of variances, Duncan's multiple range test (multiple $F$ test) was used to identify the difference in means. Meanwhile Fisher's least significant difference (LSD) would be employed as references to confirm the statistical differences. If the data violated the assumption of homogeneity of variances, Welch's Anova was used and post-hoc methods of Dunnett's T3 test employed to identify the significance or otherwise of the differences. Statistical significance is $p<0.05$. Mean \pm standard deviation was used to describe the statistical data.

By employing the analytic hierarchy process (AHP) technique, the following structural analysis model was established for evaluating the nutritional value of fish meal, isopod meal and krill powder: amino acids, fatty acids, vitamins and minerals (Fig. 2).

Nutritional value was assessed based on the considered views of 3 nutritional experts in a small advisory committee, including expertise in human nutrition education (Lingnan Normal University. China), in swine nutrition (Jiangsu AnYou Biotechnology Group Co., Ltd. China), and one researcher with expertise in aquaculture nutrition (Ocean University of China, China). According to the scoring criteria in Table 2, each of them rated the nutritional components of the substrates and assessed the accuracy of the nutritional value judged by the four nutritional indicators. 
Table 2

Table of relative scores

\begin{tabular}{|c|c|}
\hline Value of $j \& k^{*}$ & Interpretation \\
\hline 1 & $j$ and $k$ are equally important \\
\hline 3 & $j$ is slightly more important than $k$ \\
\hline 5 & $j$ is more important than $k$ \\
\hline 7 & $j$ is strongly more important than $k$ \\
\hline 9 & $j$ is absolutely more important than $k$ \\
\hline $2,4,6,8$ & intermediate value in two adjacent judgments \\
\hline
\end{tabular}

The judgment matrices of each were imported into the group decision system and tested for consistency by YAAHP(Yet Another AHP)V.10.0 software. Upon testing, all the matrices form from the scores of three experts met the consistency requirement (consistency ratio $=0.0981,0.0000,0.0398$, respectively). The total sequencing weight value was obtained through arithmetical average, which calculated from the matrices given by experts.

\section{Results}

\section{Growth performance of juvenile Ligia exotica}

As shown in Fig. 3, the average body weight of the new-hatched juveniles of Ligia exotica is $0.24 \pm 0.005 \mathrm{mg}$. The increase of body weight (BW) in the early stages is not significant until 15 days after hatching (DAH), after that BW increases from $0.85 \pm 0.02 \mathrm{mg}$ to $6.37 \pm 0.04 \mathrm{mg}$ at $45 \mathrm{DAH}$. From then on, the weight gain of individuals begins to accelerate significantly, reaching $12.69 \pm 0.01 \mathrm{mg}$ at $55 \mathrm{DAH}$ and $16.37 \pm 0.41 \mathrm{mg}$ at 60 $\mathrm{DAH}$. The exponential growth equation of juveniles Ligia is $\mathrm{y}=0.3485 \mathrm{e}^{0.3119 \mathrm{x}}$, and the correlation index $\mathrm{R}^{2}$ is 0.93 , which demonstrate a good positive correlation of body weight gain over time. The final BW value of Ligia at $70 \mathrm{DAH}$ is $31.06 \pm 1.06 \mathrm{mg}$. Weight gain rate of juvenile Ligia is (final BW-initial BW) / initial BW $\times 100 \%$ is $13026.76 \%$. Specific growth rate per day is (In final BW - In initial BW ) / DAH $\times 100 \%$ is $6.97 \%$.

\section{General nutritional components of Ligia}

As shown in Table 3, the crude protein of isopod meal is less than both the krill meal and fishmeal $(F=225.18$, $\mathrm{df}=2)$. The crude fat $(\mathrm{F}=224.02, \mathrm{df}=2)$ and cholesterol content $(\mathrm{F}=1430.29, \mathrm{df}=2)$ of the isopod meal is lower whereas, the crude ash content $(F=237.64, d f=2)$ of isopod meal is higher than krill and fishmeal.

Table 3.

General nutritional components of isopod meal, antarctic krill meal and fishmeal $(\square$, wet weight \pm SD) 


\begin{tabular}{llllll}
\hline \multicolumn{7}{c}{ Crude protein (\%) } & Crude fat (\%) & Crude ash (\%) & Moisture (\%) & Cholesterol (mg/100g) \\
\hline isopod meal & $43.45^{\mathrm{a}} \pm 0.68$ & $8.99^{\mathrm{a}} \pm 0.15$ & $27.14^{\mathrm{c}} \pm 0.67$ & $10.89 \pm 0.07$ & $146.67^{\mathrm{a}} \pm 4.16$ \\
krill meal & $61.5^{\mathrm{b}} \pm 0.84$ & $13.97^{\mathrm{c}} \pm 0.34$ & $15.12^{\mathrm{a}} \pm 0.14$ & $9.66 \pm 0.10$ & $370.33^{\mathrm{c}} \pm 1.53$ \\
fishmeal & $60.17^{\mathrm{b}} \pm 1.69$ & $11.12^{\mathrm{b}} \pm 0.33$ & $18.95^{\mathrm{b}} \pm 0.99$ & $10.24 \pm 0.04$ & $215^{\mathrm{b}} \pm 7.93$ \\
\hline
\end{tabular}

Numerical values marked with the same letter ${ }^{\mathrm{a}, \mathrm{b}}$ or $^{\mathrm{c}}$ are not statistically significantly different.

\section{Amino Acids Composition}

Table 4 shows the composition and content of 18 amino acids and taurine in isopod meal, antarctic krill meal and fish meal. 
Table 4

Amino acids composition of isopod meal, antarctic krill meal and fish meal (\%, dry weight)

\begin{tabular}{|c|c|c|c|}
\hline Amino acids(g/100g) & isopod meal & krill meal & fish meal \\
\hline Aspartate (Asp) ${ }^{f}$ & $4.16 \pm 0.03^{\mathrm{a}}$ & $4.97 \pm 0.04^{b}$ & $6.68 \pm 0.02^{c}$ \\
\hline Threonine $(T h r)^{\mathrm{e}}$ & $1.86 \pm 0.02^{\mathrm{a}}$ & $1.92 \pm 0.03^{b}$ & $2.98 \pm 0.03^{c}$ \\
\hline Serine (Ser) & $1.38 \pm 0.05^{\mathrm{a}}$ & $2.02 \pm 0.02^{b}$ & $3.18 \pm 0.02^{c}$ \\
\hline Glutamate $(\mathrm{Glu})^{\mathrm{f}}$ & $4.66 \pm 0.02^{\mathrm{a}}$ & $7.06 \pm 0.02^{b}$ & $9.62 \pm 0.00^{c}$ \\
\hline Glycine $(G l y)^{f}$ & $6.96 \pm 0.02^{c}$ & $2.04 \pm 0.02^{\mathrm{a}}$ & $4.43 \pm 0.03^{b}$ \\
\hline Alanine $(\text { Ala })^{f}$ & $2.11 \pm 0.03^{a}$ & $2.56 \pm 0.05^{b}$ & $4.35 \pm 0.03^{c}$ \\
\hline Valine $(\mathrm{Val}) \mathrm{e}$ & $3.90 \pm 0.04^{c}$ & $2.38 \pm 0.03^{a}$ & $3.44 \pm 0.02^{b}$ \\
\hline Methionine (Met) ${ }^{\mathrm{e}}$ & $0.54 \pm 0.01^{\mathrm{a}}$ & $1.46 \pm 0.02^{b}$ & $1.72 \pm 0.04^{c}$ \\
\hline Isoleucine (Ile) e & $1.19 \pm 0.02^{\mathrm{a}}$ & $2.41 \pm 0.02^{b}$ & $2.91 \pm 0.04^{c}$ \\
\hline Leucine (Leu) ${ }^{\mathrm{e}}$ & $4.26 \pm 0.02^{b}$ & $3.90 \pm 0.01^{\mathrm{a}}$ & $5.50 \pm 0.03^{c}$ \\
\hline Tyrosine (Tyr) e & $1.76 \pm 0.01^{b}$ & $1.68 \pm 0.00^{\mathrm{a}}$ & $2.40 \pm 0.01^{c}$ \\
\hline Phenylalanine (Phe) ${ }^{\mathrm{e}}$ & $1.84 \pm 0.02^{\mathrm{a}}$ & $2.39 \pm 0.04^{b}$ & $2.84 \pm 0.01^{\mathrm{C}}$ \\
\hline Lysine (Lys) e & $3.36 \pm 0.02^{\mathrm{a}}$ & $3.72 \pm 0.01^{b}$ & $5.39 \pm 0.04^{c}$ \\
\hline Histidine (His) & $0.99 \pm 0.04^{\mathrm{a}}$ & $2.01 \pm 0.01^{c}$ & $1.62 \pm 0.02^{b}$ \\
\hline Arginine (Arg) & $4.24 \pm 0.00^{b}$ & $2.94 \pm 0.02^{a}$ & $4.50 \pm 0.03^{c}$ \\
\hline Proline (Pro) & $2.37 \pm 0.03^{b}$ & $1.68 \pm 0.04^{a}$ & $3.15 \pm 0.00^{c}$ \\
\hline Cysteine (Cys) e & $0.09 \pm 0.03^{a}$ & $1.34 \pm 0.02^{b}$ & $1.37 \pm 0.02^{b}$ \\
\hline Tryptophan (Trp) e & $0.61 \pm 0.01^{\mathrm{a}}$ & $0.88 \pm 0.04^{b}$ & $0.62 \pm 0.01^{\mathrm{a}}$ \\
\hline taurine $^{f}$ & $9.45 \pm 0.08^{c}$ & $2.93 \pm 0.04^{b}$ & $2.04 \pm 0.05^{a}$ \\
\hline$\Sigma \mathrm{AA}$ & $55.61 \pm 0.77^{b}$ & $50.11 \pm 0.37^{a}$ & $68.55 \pm 0.30^{c}$ \\
\hline
\end{tabular}

Note: Values are means of triple determination \pm standard error

$\Sigma A A$ is total amino acids, $\Sigma E A A$ is total essential amino acids $\square$ NEAA is total nonessential amino acids $\square$ $\Sigma A A$ is total flavor amino acids.

Amino acids marked ${ }^{e}$ means essential amino acids, while ${ }^{f}$ means flavor amino acid.

Numerical values marked with the same letter ${ }^{a}, b$ or ${ }^{c}$ are not statistically significantly different. 


\begin{tabular}{|c|c|c|c|}
\hline Amino acids(g/100g) & isopod meal & krill meal & fish meal \\
\hline$\Sigma$ EAA & $19.57 \pm 0.58^{a}$ & $20.73 \pm 0.68^{b}$ & $27.74 \pm 0.42^{c}$ \\
\hline ¿NEAA & $36.73 \pm 0.57^{b}$ & $29.41 \pm 0.18^{a}$ & $40.63 \pm 1.07^{c}$ \\
\hline$\Sigma F A A$ & $27.45 \pm 0.47^{b}$ & $19.54 \pm 0.9$ a & $27.28 \pm 0.11^{b}$ \\
\hline$\Sigma \mathrm{EAA} / \Sigma \mathrm{AA}(\%)$ & $35.21 \pm 0.46^{a}$ & $41.38 \pm 1.01^{b}$ & $40.47 \pm 0.50^{b}$ \\
\hline$\Sigma \mathrm{EAA} / \Sigma \mathrm{NEAA}(\%)$ & $53.29 \pm 1.12^{\mathrm{a}}$ & $70.52 \pm 2.07^{b}$ & $68.34 \pm 0.81^{b}$ \\
\hline$\Sigma \mathrm{FAA} / \Sigma \mathrm{AA}(\%)$ & $49.37 \pm 0.48^{a}$ & $38.98 \pm 1.76^{b}$ & $39.80 \pm 0.18^{b}$ \\
\hline \multicolumn{4}{|c|}{ Note: Values are means of triple determination \pm standard error } \\
\hline \multicolumn{4}{|c|}{$\begin{array}{l}\Sigma A A \text { is total amino acids, } \Sigma E A A \text { is total essential amino acids } \square \Sigma \text { NEAA is total nonessential amino } \\
\text { acids } \square \Sigma F A A \text { is total flavor amino acids. }\end{array}$} \\
\hline \multicolumn{4}{|c|}{ Amino acids marked ${ }^{e}$ means essential amino acids, while ${ }^{f}$ means flavor amino acid. } \\
\hline
\end{tabular}

The total amino acid content ( $\Sigma A A)$ of isopod meal is higher than that of krill meal but significantly lower than the total amino acids of fish meal $(F=989.81, \mathrm{df}=2)$. The contents of the nine essential amino acids $\left(\sum E A A\right)$ differ with the lowest values in Ligia $(F=181.36, \mathrm{df}=2)$. While the ratio of essential amino acids to the total amount of amino acids ( $\Sigma E A A / \Sigma A A)$ of isopod meal is the lowest in those three substrates $(F=17.92, d f=2)$. Surprisingly however, the content of taurine, a beneficial non-protein amino acid, is much greater in Ligia than that of krill meal and fish meal $(F=784.36, d f=2)$. In terms of the content of five flavored amino acids, the amino acid content of isopod meal is higher than that of krill powder $(F=91.28, d f=2)$, and its proportion to the total amino acid ( $\Sigma F A A / \Sigma A A)$ is also higher than both of krill meal and fish meal $(F=51.10, d f=2)$.

\section{Nutritional Evaluation Of Amino Acids}

The amino acid score (AAS), chemical score (CS, the limiting amino acid index) and essential amino acid index (EAAl) were calculated by converting the data in Table 4 into milligrams of amino acid per gram of nitrogen $(\times 62.5)$. The results were compared with the amino acid scoring standard pattern suggested by $\mathrm{FAO} / \mathrm{WHO}$ and the amino acid pattern of whole egg protein as described later.

Amino Acid Score (AAS) and Chemical Score (CS) reflect the relationship of protein composition and utilization ratio from different perspectives. As can be seen from Table 5, the superscript letters indicate clearly that in most of the case, the lowest scores of amino acids are in isopod category, while lle and Met + Cys may be the most distinct that less than half of those of krill meal and fishmeal $(F=3024.7, F=2392.19$ respectively for $A A S$, and $F=2935.5, F=2392.19$ for $C S$. All $d f=2$ ). Methionine and cystine are therefore the main limiting amino acids of isopod as suggested by their content. EAAl index reflects how close the essential amino acid content of material is to the standard protein (egg protein). Comparing the values of EAAl of isopod meal, krill 
meal and fishmeal, indicates that the protein quality of the isopod is worse than that of krill meal and fishmeal $(F=1294.4, d f=2)$. Most of the highest AAS and CS scores of fishmeal demonstrate that fishmeal is rich in essential amino acids and it is well-balanced in composition, therefore easy to be digested and absorbed by human.

\section{Nutritional Composition Of Fatty Acid}

Table 6 shows the fatty acid composition of isopod meal, krill meal and fish meal. There are 12 fatty acids including 3 saturated fatty acids (SFA), 3 monounsaturated fatty acids (MUFA) and 6 polyunsaturated fatty acids (PUFA) in isopod meal. 14 fatty acids were detected in krill meal, including 4 SFA,4 MUFA,6 PUFA, while all 4 SFA, 6 MUFA and 7 PUFA were found in fish meal. The content of saturated fatty acid (SFA) in isopod meal is like that of krill but higher than that in fish meal $(F=18.00, d f=2)$, which may show that its fatty acid characteristics are closer to those of terrestrial animals. The content of monounsaturated fatty acids (SFA, F = $71.11, d f=2)$, and EPA and DHA are the lowest in the isopod $(F=367.63$ and $F=311.70$ respectively, while $d f=$ 2). Although the content of $n-6$ PUFA is slightly higher in the isopod than that of krill meal $(F=55.69, d f=2)$, the total content of PUFA is far lower than either krill meal or fishmeal $(F=117.81, d f=2)$. 
Table 6

Fatty acids content of isopod meal, Antarctic krill meal and fishmeal

\begin{tabular}{|c|c|c|c|}
\hline Fatty acids & isopod meal & krill meal & fishmeal \\
\hline C14:0 / C16:0 & $\begin{array}{l}1.95 \pm 0.04 \text { a/ } 27.33 \pm \\
0.01^{\mathrm{a}}\end{array}$ & $\begin{array}{l}8.90 \pm 0.02^{c} / 22.89 \pm \\
0.01^{b}\end{array}$ & $\begin{array}{l}5.90 \pm 0.04^{b} / 17.32 \pm \\
0.02^{c}\end{array}$ \\
\hline C17:0 / C18:0 & None/ $4.39 \pm 0.02^{c}$ & $\begin{array}{l}0.26 \pm 0.03 / 1.20 \pm 0.02 \\
\mathrm{a}\end{array}$ & $0.58 \pm 0.02 / 2.78 \pm 0.01^{b}$ \\
\hline$\Sigma$ SFA & $33.66 \pm 2.01^{b}$ & $33.13 \pm 1.21^{b}$ & $26.88 \pm 1.27^{a}$ \\
\hline C16:1 / C17:1 & $11.22 \pm 0.03^{c} /$ None & $6.93 \pm 0.02^{a} /$ None & $8.31 \pm 0.03^{b} / 0.32 \pm 0.02$ \\
\hline $\begin{array}{l}\text { C18:1 n9 C / C20:1 } \\
\text { n9 }\end{array}$ & $7.48 \pm 0.01^{a} /$ None & $\begin{array}{l}18.0 \pm 0.02^{c} / 1.64 \pm \\
0.02^{b}\end{array}$ & $\begin{array}{l}15.29 \pm 0.01^{b} / 0.85 \pm \\
0.03^{a}\end{array}$ \\
\hline C22:1 n9 / C24:1 n9 & None / $0.57 \pm 0.02$ & None / None & $1.19 \pm 0.02 / 0.81 \pm 0.05$ \\
\hline$\Sigma$ MUFA & $19.28 \pm 1.22^{\mathrm{a}}$ & $26.57 \pm 0.46^{b}$ & $26.61 \pm 0.75^{b}$ \\
\hline $\begin{array}{l}\text { C18:2 n6 c / C18:3 } \\
\text { n6 }\end{array}$ & $\begin{array}{l}10.11^{ \pm} 0.04^{c} / 0.33 \pm \\
0.01^{c}\end{array}$ & $\begin{array}{l}3.10 \pm 0.05^{b} / 0.40 \pm \\
0.01^{b}\end{array}$ & $\begin{array}{l}1.79 \pm 0.02 \mathrm{a} / 0.04 \pm 0.00 \\
\mathrm{a}\end{array}$ \\
\hline C18:3 n3 & $3.41 \pm 0.02^{c}$ & $0.94 \pm 0.02^{b}$ & $1.05 \pm 0.011^{\mathrm{a}}$ \\
\hline C20:2 n6/ C20:3 n6 & $0.5 \pm 0.02^{a} / 0.29 \pm 0.02^{a}$ & $\begin{array}{l}4.21 \pm 0.04^{c} / 0.32 \pm \\
0.03^{a}\end{array}$ & $\begin{array}{l}2.06 \pm 0.03^{b} / 12.94 \pm \\
0.04^{b}\end{array}$ \\
\hline C20:3 n3 / C20:4 n6 & $0.31 \pm 0.02 /$ None & None / $0.51 \pm 0.06$ & $0.31 \pm 0.01 / 0.70 \pm 0.02$ \\
\hline EPA C20:5 n3 & $6.54 \pm 0.01^{\mathrm{a}}$ & $18.30 \pm 0.02^{c}$ & $14.70 \pm 0.02^{b}$ \\
\hline DPA C22:5 n3 & $0.62 \pm 0.02^{b}$ & $0.44 \pm 0.03^{a}$ & $1.13 \pm 0.02^{c}$ \\
\hline DHA C22:6 n3 & $1.27 \pm 0.03^{\mathrm{a}}$ & $12.30 \pm 0.02^{b}$ & $12.95 \pm 0.06^{c}$ \\
\hline $\mathrm{EPA}+\mathrm{DPA}+\mathrm{DHA}$ & $8.40 \pm 0.27^{a}$ & $31.01 \pm 1.56^{c}$ & $28.70 \pm 1.09^{b}$ \\
\hline$\Sigma$ n-3 PUFA & $12.12 \pm 0.3^{\mathrm{a}}$ & $31.96 \pm 1.57^{b}$ & $30.06 \pm 1.09^{b}$ \\
\hline$\Sigma \mathrm{n}-6$ PUFA & $11.50 \pm 0.70^{b}$ & $8.55 \pm 0.19^{a}$ & $17.18 \pm 1.60^{c}$ \\
\hline$\Sigma$ PUFA & $23.61 \pm 0.99^{a}$ & $40.50 \pm 1.76^{b}$ & $47.27 \pm 2.69^{c}$ \\
\hline
\end{tabular}

Note: Values are means of triple determination \pm standard error

Numerical values marked with the same letter ${ }^{a, b}$ or $^{c}$ are not statistically significantly different.

SFA: Saturated Fatty Acids; MUFA: Monounsaturated Fatty Acids; PUFA: Polyunsaturated Fatty Acids; ND: Not Detected 


\begin{tabular}{|lccc|}
\hline Fatty acids & isopod meal & krill meal & fishmeal \\
\hline $\begin{array}{l}\sum \text { n-3 PUFA } / \Sigma \mathrm{n}-6 \\
\text { PUFA }\end{array}$ & $1.06 \pm 0.04^{\mathrm{a}}$ & $3.74 \pm 0.1^{\mathrm{b}}$ & $1.76 \pm 0.1^{\mathrm{c}}$ \\
\hline Note: Values are means of triple determination \pm standard error & \\
\hline Numerical values marked with the same letter ${ }^{\mathrm{a}, \mathrm{b}}$ or $^{\mathrm{c}}$ are not statistically significantly different. \\
\hline $\begin{array}{l}\text { SFA: Saturated Fatty Acids; MUFA: Monounsaturated Fatty Acids; PUFA: Polyunsaturated Fatty Acids; ND: } \\
\text { Not Detected }\end{array}$ \\
\hline
\end{tabular}

\section{Comparison Of Vitamin Composition}

As shown in Table 7 the vitamin composition of isopod meal is relatively comprehensive. Among the four fatsoluble vitamins, the content of VA is lower in the isopod than in fish meal, while the contents of VK1 and VE $\left(F=1.81 \times 10^{5}, \mathrm{df}=2\right)$ are much higher than those in krill and fish meal. In addition, the contents of watersoluble vitamin $\mathrm{VB}_{2}\left(\mathrm{~F}=1.30 \times 10^{5}, \mathrm{df}=2\right), \mathrm{VB}_{3}(\mathrm{t}=19.13, \mathrm{df}=2)$ and $\mathrm{VB}_{5}$ are the highest in isopod meal among the three materials. 
Table 7

Vitamin composition of isopod meal, Antarctic krill meal and fishmeal

\begin{tabular}{|c|c|c|c|}
\hline Vitamin (mg/100 g) & Isopod meal & Krill meal & Fish meal \\
\hline VA (retinol) & $\varangle 0.05$ & $\otimes 0.05$ & $0.19 \pm 0.05$ \\
\hline $\mathrm{VD}_{3}$ (cholecalciferol, $\mu \mathrm{g} / 100 \mathrm{~g}$ ) & $\otimes 2$ & $\varangle 2$ & $凶 2$ \\
\hline $\mathrm{VK}_{1}$ (phylloquinone, $\mu \mathrm{g} / 100 \mathrm{~g}$ ) & $64.0 \pm 3$ & $\otimes 1$ & $\nabla 1$ \\
\hline VE (tocopherol) & $9.32 \pm 0.14^{c}$ & $2.53 \pm 0.03^{b}$ & $0.82 \pm 0.01^{\mathrm{a}}$ \\
\hline $\mathrm{VB}_{1}$ (thiamine) & ND & $0.04 \pm 0.00$ & ND \\
\hline $\mathrm{VB}_{2}$ (riboflavin) & $1.68 \pm 0.00^{\mathrm{b}}$ & $0.12 \pm 0.00^{\mathrm{a}}$ & $0.12 \pm 0.00^{a}$ \\
\hline $\mathrm{VB}_{3}$ (niacin) & $2.83 \pm 0.28^{b}$ & $1.41 \pm 0.41^{\mathrm{a}}$ & ND \\
\hline $\mathrm{VB}_{5}$ (pantothenic acid) & $2.43 \pm 0.52$ & ND & ND \\
\hline $\mathrm{VB}_{6}$ (pyridoxine, mg/kg) & ND & ND & ND \\
\hline $\mathrm{VB}_{12}$ (cobalamin, mg/kg) & ND & $0.849 \pm 0.18$ & ND \\
\hline Folic acid (mg/kg) & ND & ND & ND \\
\hline VC (ascorbic acid) & $\otimes 1$ & $\otimes 1$ & $\nabla 1$ \\
\hline \multicolumn{4}{|l|}{ Note: ND, Not Detected. } \\
\hline \multicolumn{4}{|c|}{ Values are means of triple determination \pm standard error. } \\
\hline
\end{tabular}

\section{Comparison Of Mineral Composition}

The mineral composition of Ligia exotica is shown in Table 8. Ubiquitous mineral elements such as calcium $(F=3995.94, d f=2)$, potassium $(F=590.06, d f=2)$ and magnesium $(F=658.60, d f=2)$ are most abundant in the isopod. Trace mineral element ferrum $(F=13185.74, d f=2)$ is also the richest in the isopod, whilst copper content $(F=160.04, d f=2)$ in both isopod and krill meal is higher than that in fishmeal. Chromium $(F=33.59$, $\mathrm{df}=2)$ and selenium $(\mathrm{F}=406.02, \mathrm{df}=2)$ are also the highest in the isopod. 
Table 8

Minerals composition of isopod meal, Antarctic krill meal and fishmeal

\begin{tabular}{|c|c|c|c|}
\hline Minerals(mg/kg) & Isopod meal & Krill meal & Fish meal \\
\hline calcium & $90283 \pm 618.41^{c}$ & $21536.04 \pm 1484.63^{b}$ & $18575.06 \pm 1058.80^{a}$ \\
\hline potassium & $5403.4 \pm 59.88^{c}$ & $2378.68 .15 \pm 136.90^{a}$ & $3352.11 \pm 118.47^{b}$ \\
\hline sodium & $8117.13 \pm 126.96^{b}$ & $10592.23 \pm 615.4^{c}$ & $4033.63 \pm 418.27^{a}$ \\
\hline magnesium & $4862.67 \pm 40.55^{c}$ & $4517.53 \pm 204.63^{b}$ & $1256.98 \pm 102.84^{a}$ \\
\hline copper & $31.00 \pm 2^{b}$ & $70.76 \pm 7.62^{c}$ & $4.74 \pm 7.62^{a}$ \\
\hline ferrum & $882.67 \pm 7.37^{c}$ & $84.27 \pm 10.08^{b}$ & $22.10 \pm 1.13^{a}$ \\
\hline zinc & $62.95 \pm 2.76^{b}$ & $52.04 \pm 2.85^{a}$ & $74.40 \pm 4.22^{c}$ \\
\hline chromium & $2 \pm 0.14$ & None & None \\
\hline selenium & $2.69 \pm 0.12^{c}$ & $1.54 \pm 0.13^{b}$ & $0.4 \pm 0.00^{a}$ \\
\hline manganese & $60.67 \pm 2.52^{a}$ & $2.6 \pm 0.2^{c}$ & $25 \pm 2^{b}$ \\
\hline total phosphorus (\%) & $0.43 \pm 0.02^{c}$ & $1.42 \pm 0.04^{a}$ & $1.15 \pm 0.08^{b}$ \\
\hline \multicolumn{4}{|c|}{ Note: Values are means of triple determination \pm standard error. } \\
\hline $\begin{array}{l}\text { Numerical values ma } \\
0.05 \text { level. }\end{array}$ & the same letter & are not statistically & nt different at the $p<$ \\
\hline
\end{tabular}

\section{Comprehensive comparison of amino acids, fatty acids, vitamins and minerals}

Based on the group decision hierarchy process software YAAHP (Yet Another Analytic Hierarchy Process Software, V10.0) to summaries of expert judgment, the weighted index nutritional value was calculated, as shown in Fig. 4.

For human or animal consumption, the importance of amino acids, fatty acids, vitamins and minerals are different (blue numbers in the middle of Fig. 4 show the weight of the elements, the larger the number, the greater the importance of the index, and the following blue numbers in the bottom of Figure mean the same). On this basis, fishmeal is the most preferable substrate, and isopod meal is the worst, due largely to its imbalance in nutritional elements.

In order to better visualize the differences of nutrient composition of the three food materials, a radar chart (Fig. 5) was constructed including essential amino acids, flavor amino acids, essential amino acid index, $\Sigma$ PUFA, vitamins (8 parameters) and minerals (9 parameters). The rank order of the three food materials for each of the main nutrient category is based on the top rank having the highest value in the number of parameters, followed by the second and third respectively, considering that numerous parameters are involved. 
For example, in the mineral category, isopod substrate has six the highest parameters, followed by krill with two and fishmeal one (Table 8), so they are ranked first, second and third respectively. To facilitate comparison with other factors in the radar chart, numbers " 50 ", " 40 ", "30" were assigned to the first, second and third ranked materials respectively, while factors of $\Sigma F A A$ / $\Sigma A A(\%), \Sigma E A A / \Sigma A A(\%)$, EAAl and $\Sigma P U F A$ were scored based on the actual values from Table 4, Table 5 and Table 6.

As can be seen from Fig. 5, there are clear differences between the assessed nutritional value of isopod, krill and fish meal. Isopod substrate scores better in minerals and vitamin content, and has a certain flavor stimulating effect (view from $\Sigma F A A$ / $\Sigma A A(\%)$ ). However, fatty acid content, especially $\Sigma P U F A$, is far lower than that of krill meal and fish meal. Fish meal scores best in EAAI andEPUFA. Unsaturated fatty acids are known to have beneficial physiological functions such as improving blood microcirculation and increasing the activity of brain cells. The closer the protein composition is to the egg protein, the easier it absorbed and utilized by humans (view from EAAI). To sum up, the nutritional value of isopod is inferior to that of krill and fish meal.

\section{Discussion}

Ligia species are distributed all over the world and Ligia exotica is probably the most widely distributed among about 30 species of the genus. Based on the data presented in Hourado et al, 2018. The sites sampled in this present study and after reviewing the literature on Ligia exotica, we have compiled a comprehensive list of locations where Ligia are known or generally available (Appendix 1, supporting information for online publication only ) and constructed a global distribution map (Fig. 6) generated by ArcGIS software.

L. exotica represents one of the oldest documented introductions of marine organisms (Hurtado et al, 2018), originally described by Roux (1828) at the docks in Marseille, France (ID =61, Fig. 6). This is the northernmost location, while the southernmost location is Sunday Island, Australia (Green, 1962. ID = 58, Fig. 6). They are widely distributed in tropical and temperate regions, including the Seychelles archipelago and Hawaiian Islands suggesting significant colonization ability, but the species has not been found in the Antarctic or Arctic. The southern coast of the United States and the coast of East Asia are two major hot spots. East Asia is traditionally considered to be the origin of L. exotica. In China, L. exotica is distributed all over the rocky coast (Yin, 2013), including Taiwan (ID = 35, 36. Figure 6). Areas in eastern China account for $70 \%$ of Chinese human population, whose activities not only bring a large amount of nutrients to the coastal waters by way of waste discharge and disposal, but also provide habitats to L. exotica in form of wharves and dams. Ligia $s p$. plays an important role as a scavenger/detritivore, feeding on a large range of organic matter plant debris and animal corpses brought by tides.

The only published study on Ligia growth we are aware of to date is that of Carefoot (1973) on the field population and growth of Ligia pallasii Brandt. Further work examined the nutritional requirements of Ligia pallasiii using artificial feed and demonstrated that this species is able to grow from $56.5 \mathrm{mg}$ to $111.6 \mathrm{mg}$ over 40 weeks of culture (Carefoot, 1984). The resulting specific growth rate (SGR) is only $0.24 \%$. In contrast, for the Pacific white shrimp Litopenaeus vannamei, the SGR of genetically selected high growth lines could reach $29.25 \%$ (Rosenberry, 2013). In present study, juvenile Ligia exotica have an SGR of $6.97 \%$ after 70 days of culture. 
The primary aim of this present study was to examine the nutritional value of Ligia as a potential new natural food source in aquaculture based on our previous study that confirmed that $L$. exotica provide a good diet for juvenile cuttlefish (Xu et al. 2013). However, it is still unknown how long this feed could support the growth of juvenile cuttlefish if be used as a sole diet. In comparison to both krill and fish meal, the nutritional value of protein and amino acids of Ligia isopod is lower in almost all evaluation indexes, such as crude protein content, $\Sigma$ EAA / $\Sigma A A(\%), \Sigma E A A$ / $\Sigma$ NEAA (\%), and EAAI. In particular the two amino acids with the lowest values for L. exotica, methionine and cystine, are present at less than half of that of krill meal and fishmeal. The imbalance of these amino acids may affect the digestion and absorption of predators from isopod food. However, isopods have a relative high value of $\Sigma F A A$ / $\Sigma A A(\%)$ and the contents of taurine are 4 to 5 times those of fish meal and krill. As a sulfonic acid, taurine is a found in high concentrations in animal tissues and has been attributed a wide diversity of roles in some mammals, e.g., as an essential dietary requirement for cats, and a critical supplement for marine fish feed (Salze \& Davis. 2015)

Ligia contains more saturated fatty acid (SFA) than fishmeal and krill, but carries few polyunsaturated fatty acid (PUFA), which is important to humans and other animals. This also reduces its potential nutritional value. Interestingly, however, the isopod has superior vitamin content as concentrations of $\mathrm{VK}_{1}, \mathrm{VE}, \mathrm{VB}_{2}, \mathrm{VB}_{3}$ and $\mathrm{VB}_{5}$ are all far higher than in krill and fishmeal. It should be noted that the vitamin content in substrate is highly variable, influenced by several factors, such as origin and composition of the animal, meal processing method, and product freshness (Miles \& Chapman. 2012). Under the processing methods of this study, the three substrates went through a process of heating and drying at high temperature, so for unstable vitamins such as $\mathrm{VC}, \mathrm{VB}_{1}$ and folic acid problems with detection may have occurred. In addition, part of fat-soluble vitamins in fish meal were lost during oil extraction. The mineral composition analyses show that calcium accounts for a very large proportion of body content in the isopod.

Isopods have a high tolerance to heavy metals contaminants in intertidal environment and their body concentration of metal elements are highly affected by the environment. In areas with severe anthropogenic contamination, heavy metal elements are transmitted through food chains and can accumulate in isopods (Hopkin et al. 2013). For example, high concentrations of copper in Ligia from the Santa Rosalía area are consistent with mining activities at this location (Garciahernandez et al. 2015). The area we sampled Jinsha Bay, Zhanjiang City (ID = 59, Fig. 6) is a hot spot for human activity and waste discharge, therefore it is likely that Ligia would accumulate any heavy metal pollution. The body tissues of Ligia are also very high in iron content. According to Chinese national food safety standards (GB 2762 - 2017) and the standard for the use of food fortifiers (GB14880-2012), the mineral content of L. exotica is outside of the standards as food for human consumption. Since the intertidal zones are exposed to pollution from both marine and terrestrial sources, isopods could potentially be used as biomonitors of pollution in these habitats in a similar way to terrestrial isopods in soil ecotoxicology (Gestel et al. 2017).

In China, crustacean farming for food (represented by species such as Pacific white shrimp and American crayfish) is a significant industry. The annual output of white shrimp is more than 1.5 million tons, and its gross value is more than 8.7 billion dollars. Litopenaeus vannamei also has a mineralised cuticle that sheds regularly to allow for growth. Ligia extocia, given its abundance and large geographic range therefore has the potential to become a model animal for crustacean studies related to aquaculture, to better understand some of the physiological properties of crustacea such as the shrimp that are economically important. For example, 
the calcium translocations and transepithelial movement during the moulting cycle of L.vannamei, and dietary calcium requirement in low salinity environments (Cheng et al. 2006). This undoubtedly has great theoretical and applied value.

\section{Conclusions}

In conclusion, Ligia extocia has potential to serve as an alternative natural food source in aquaculture or animal farming given the growth rate under culture, acclimatization ability and the fact that it can be cultivated either in or out of water. It is especially suitable for cuttlefish which prefer live crustacean as diet. However, the unbalanced amino acid composition and lower content of PUFA may limit its practical value. Ligia collected in the field are deemed unfit for human consumption because of the heavy metal content exceeding the provided standard. Considering its unique semi-terrestrial ability and its role in the material cycle of the coastal zone, further study is warranted to elucidate its biological characteristics.

\section{List Of Abbreviations}

Amino Acids include

Ile: Isoleucine; Leu: Leucine; Lys: Lysine; Thr: Threonine; Val: Valine; Trp: Tryptophan; Met: Methionine; Cys: Cysteine; Phe: Phenylalanine; Tyr: Tyrosine

AAS: Amino acid score

BW: Body weight

CS: Chemical score

DAH: Days after hatching

EAAl: Essential amino acid index

FAAC: Flame atomic absorption spectrometry

GB: Chinese national determination standard

HPLC: High performance liquid chromatography

ICP-MS: Inductively coupled plasma- mass spectrometry

MUFA: Monounsaturated fatty acids

ND: Not Detected

PUFA: Polyunsaturated fatty acids

RP-HPLC: Reversed-phase chromatography 
SFA: Saturated fatty acids

SGR: Specific growth rate

¿AA: Total amino acids

¿EAA: Total essential amino acids

¿NEAA: Total nonessential amino acids

\section{Declarations}

\section{Acknowledgements}

The authors would like to thank Miss Huiqi Zhou, Yirong Huang for the isopod nutritional analyses, Miss Yingzi Lei for the juveniles culture of ligia exotica, while Mr. Jianqiang Liu for the parent isopod collection in the field. The authors acknowledge all projects of different level to fund this research and thank to the experts who participated in the nutritional rating questionnaire. Finally, we sincerely thank Professor Paul Giller MRIA from University College Cork (UCC) for comments and advise on earlier versions of the manuscript.

\section{Funding}

1. The natural science research fund of Lingnan Normal University (1170918267).

2. The science and technology research project of Zhanjiang, China (2018B01103 and $2018 \mathrm{~B} 01051$ respectively).

3. The public service platform of biomedical resources research and development of south China sea (2017C8B2).

\section{conflict of interest}

No potential conflict of interest was reported by the authors.

\section{Animal welfare statement}

The authors confirm that the ethical policies of the journal, as noted on the journal's author guidelines page, have been adhered to and the appropriate ethical review committee approval has been received. The authors confirm that they have followed EU standards for the protection of animals used for scientific purposes.

\section{Supplementary information}

Appendix 1 is the supporting information for online publication only. And it is available for this paper at https://orcid.org/0000-0002-6591-8571.

Correspondence and requests for materials should be addressed to Lele.

\section{Authors' contributions}


Lele Xu designed the research study, analyzed the experimental parameters. Xiang Jiang and Yulin Sun collect the experimental material in the field. Yongqin Li wrote the paper and Daohai Chen, Haiyong Zhao polish the article in English. Haifeng Mi provide the essential laboratory and equipment to carry out the analysis. Yao Liu gave a substantial contribute to the data statistics, and Liyun Wang supervised the findings of this work. All authors discussed the results and contributed to the final manuscript.

\section{Consent for publication}

Not applicable.

\section{References}

Bian, J., Xuan, W.D. \& Chu, Z.Y. 2007. Antitumor effects of extract from Ligia exotica (Roux). Chin J Mar Drugs, 26,13-15.

Carefoot, T.H. 1973. Studies on the growth, reproduction, and life cycle of the supralittoral isopod Ligia pallasii. Mar. Biol. 18, 302-311.

Carefoot, T. H. 1973. Feeding, food preference, and the uptake of food energy by the supralittoral isopod Ligia pallasii. Mar. Biol. 18, 228-236.

Carefoot, T.H. 1984. Studies on the nutrition of the supralittoral isopod Ligia pallasii using chemically defined artificial diets: Assessment of vitamin, carbohydrate, fatty acid, cholesterol and mineral requirements. Comp. Biochem. Physiol. Part A Mol. Integr. Physiol. 79, 655-665.

Carefoot, T.H. A snail's odyssey: a journal through the research done on west-coast marine invertebrates. (2020). Available at www.asnailsodyssey.com/. (accessed on 21 January, 2020).

Chen, G.X. 1987. Notes on two species of sea cockroaches. Chin. J. Zool. 22, 8-11.

Cheng, K.M. Hu, C.Q. \& Liu Y.N. et al. 2006. Effects of dietary calcium, phosphorus and calcium / phosphorus ratio on the growth and tissue mineralization of Litopenaeus vannamei reared in low-salinity water. Aquac. $251,472-483$.

Eberl, R. 2012. Distribution, habitat and food preferences of sympatric high intertidal isopod species Ligia occidentalis and Ligia pallasii (Ligiidae: Oniscidea). J. Natur. Hist. 46, 1779-1797.

Garciahernandez, J., Hurtado, L.A. \& Leyvagarcia, G.N. et al. 2015. Isopods of the genus Ligia as potential biomonitors of trace metals from the gulf of California and pacific coast of the Baja California peninsula. Ecotoxicol. Environ. Saf. 112, 177-185.

Gestel, C.A.M.V., Loureiro, S. \& Zidar, P. 2018. Terrestrial isopods as model organisms in soil ecotoxicology: a review. ZooKeys. 801,127-162.

Green, A.J.A. 1962. Record of the occurrence in Australia of Ligia exotica Roux (Crustacea, Isopoda, Oniscoidea). Papers and Proceedings of the Royal Society of Tasmania. 96, 83-85. 
Grismer, L.L. 1994. Three new species of intertidal side-blotched lizards (Genus Uta) from the Gulf of California, México. Herpetologica 50, 451-474.

Hopkin, S.P., Martin, M.H. \& Moss, S.J. 1985. Heavy metals in isopods from the supralittoral zone on the Southern shore of the Severn Estuary. UK. Env. Pollut. 9, 239-254.

Horiguchi, H., Hariyama, T., Takano, S., \& Yamagishi, H. 2006. Photosensitive neurogenic heart of the isopod crustacean Ligia exotica. Proc. Biol. Sci. 273, 2535-2540.

Huang, Z.Q., Zhao,L., Sun, J.X. \& Zhang P. 2018. Status, problems and perspectives on the systematic biology of genus Ligia: A review. Chin. J. Ecol. 37, 960-966.

Hurtado, L.A., Mateos, M. \& Santamaria, C. A. 2010. Phylogeography of supralittoral rocky intertidal Ligia isopods in the Pacific region from central California to central Mexico. Plos One. 5, e11633

Hurtado, L.A., Mateos, M., \& Wang, C., et al. 2018. Out of Asia: mitochondrial evolutionary history of the globally introduced supralittoral isopod Ligia exotica. Peer. J, 4337.

Miles, R.D. \& Chapman, F.A. 2012. The benefits of fishmeal in aquaculture diets. Univ. Florida EDIS. FA122.

Pellett, P.L. \& Yong, V.R. 1980. Chemical and microbiological assays of protein quality. Nutritional evaluation of protein foods. 26-29.

Roux, P. 1828. Crustacés de la Méditerranée et de son littoral. Marseille: Levrault.

Rosenberry, B. 2013. Growth curves for genetically selected high growth lines of Litopenaeus vannamei. Shrimp News International. Available at

https://www.shrimpnews.com/FreeReportsFolder/NewsReportsFolder/USATexasVannameiGrowthCurves.html (accessed on 18 December 2019).

Salze, G.P. \& Davis, D.A. 2015. Taurine: a critical nutrient for future fish feeds. Aquac.437, 215-229.

Seong, H.K., Su, M.Y., II S. P. \& Yong, H.K. 2000. A new inosine disaccharide from the crustacean Ligia exotica: isolation and structure elucidation by total synthesis. J. Nat. Prod. 63, 1188-1191.

Sun, J.X. Xing, X.L. \& Zhang P. 2015. Advances on the biology and ecophysiology of the genus Ligia. Chin. J. Biol. 32, 86-90.

Taiti, S., Arnedo, M.A., Lew, S.E, \& Roderick, G.K. 2003. Evolution of terrestriality in Hawaiian species of the genus Ligia (Isopoda, Oniscidea). Crustaceana Monographs, V: 85-102.

WHO. 1985. Report of a Joint FAO/WHO/UNU Expert Consultation. Factors affecting energy and protein requirement. Energy and protein requirements. Available at http://www.fao.org/3/AA040E/AA040E08.htm\#ch7.3. (accessed on 13 August 2019).

Xu, L.L., Li Yongqin, et al. 2018. Can Sepia pharaonis be reared on sea roach, Ligia exotica, from the first day after hatching? Cephalopod International Advisory Council Conference. 
Yin, J.W. 2013. Species assignment and comparative phylogeographic studies on the genus Ligia (Crustacea: Malacostraca: Isopoda: Ligiidea) coastally distributed in Chinese Mainland. Nanjing Normal University. Ph D dissertation.

Yin, J.W., Pan, D., He, C., Wang, A., Yan, J., \& Sun, H.Y. 2013. Morphological and molecular data confirm species assignment and dispersal of the genus Ligia (Crustacea: Isopoda: Ligiidae) along northeastern coastal China and East Asia. Zool. J. Linn. Soc. 169, 362-376.

\section{Figures}

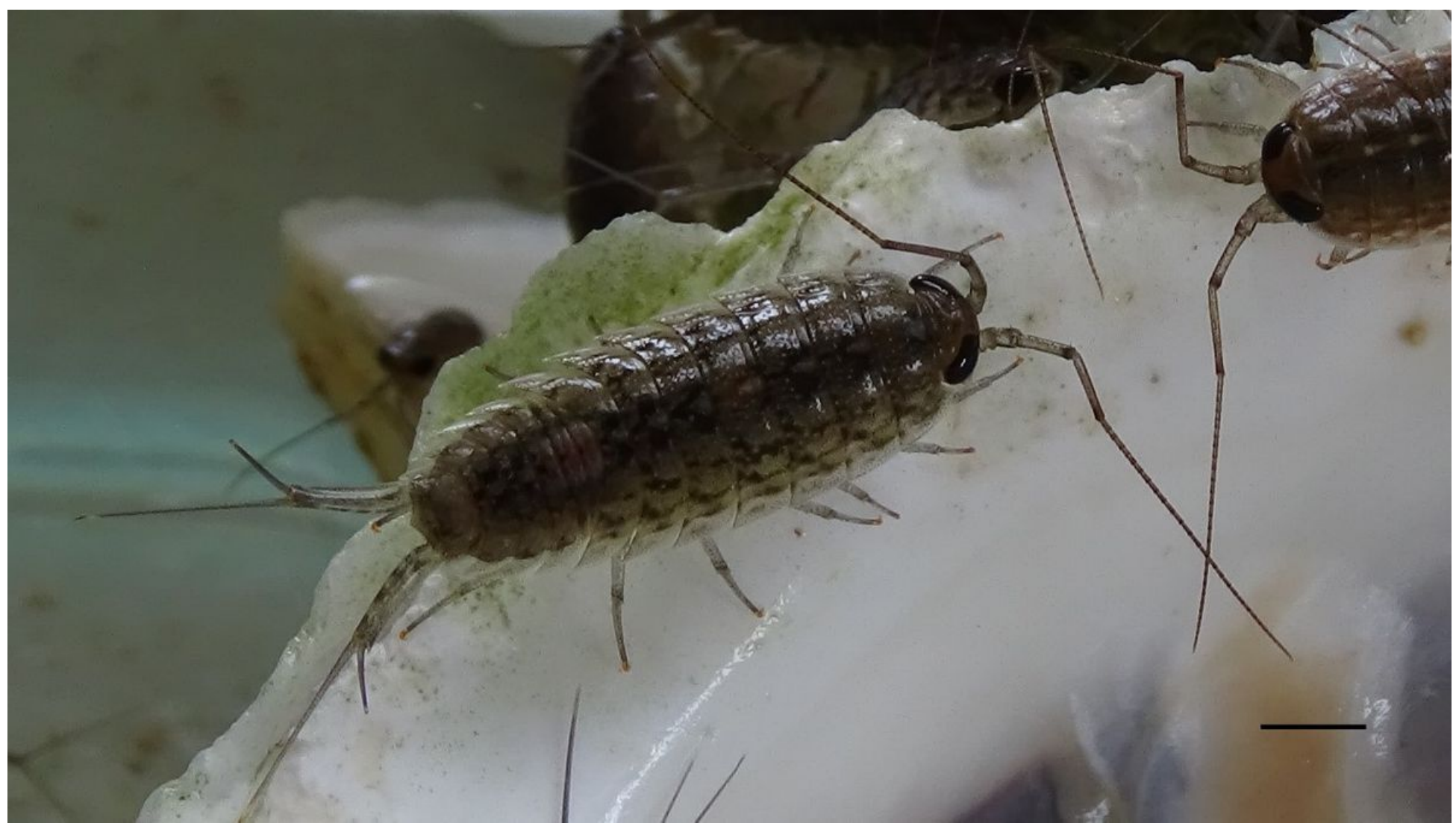

\section{Figure 1}

External morphology of Ligia exotica (scale bar $=0.6 \mathrm{~cm}$ ) 


\section{nutritional value}

\section{Goal}

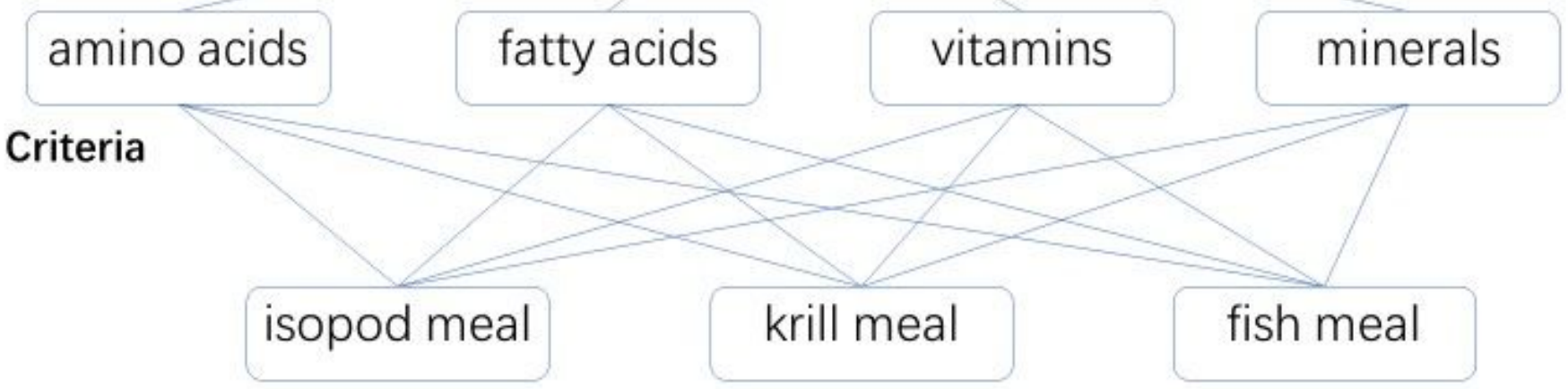

\section{Alternatives}

Figure 2

Analytical hierarchy process model of nutritional value for L.exotica

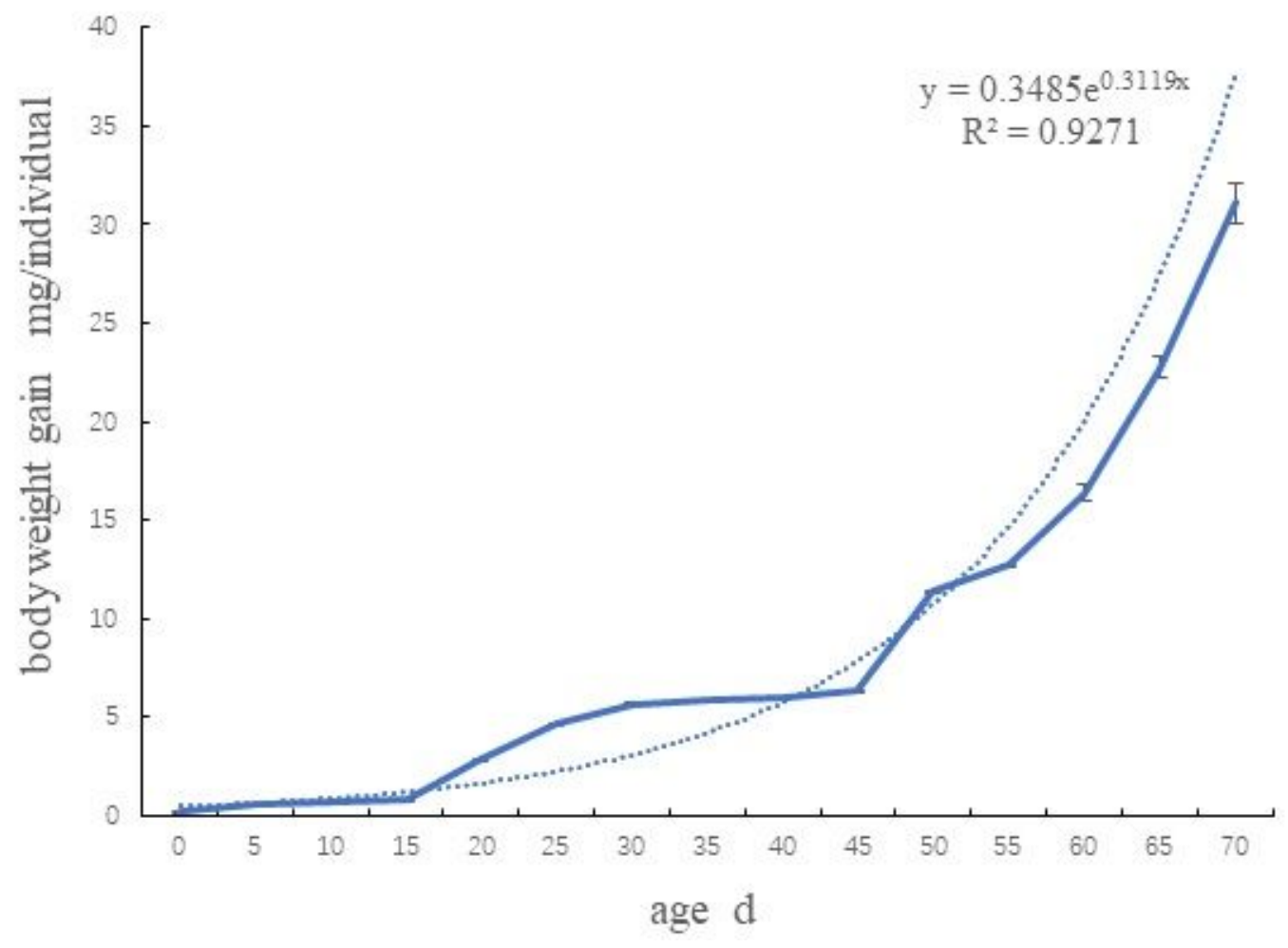

Figure 3 
Growth curve (body weight gain over time) of juvenile Ligia exotica ( $n=3$ groups, each contain 10 individuals from the same female. \pm Bar means standard error)

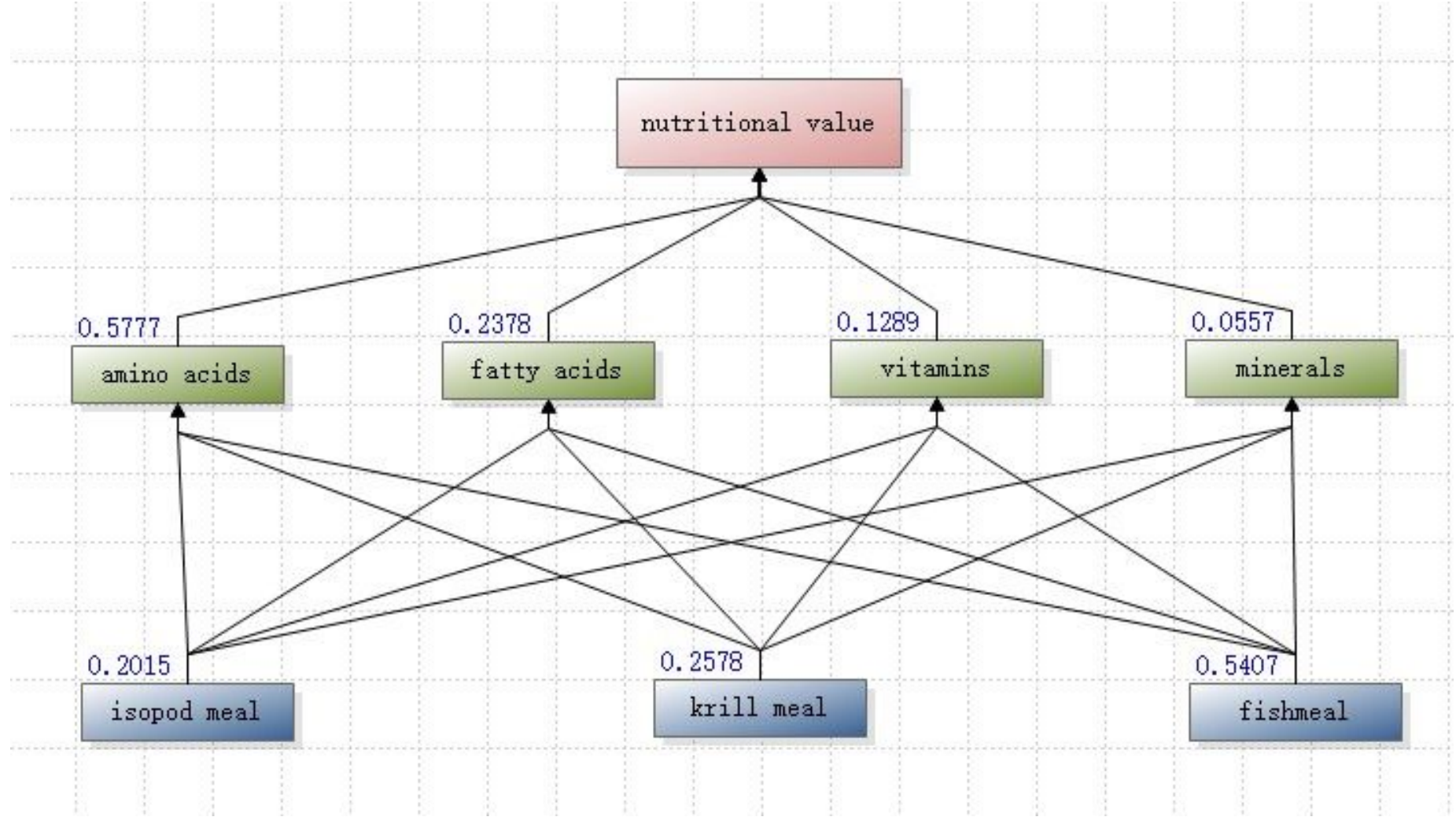

Figure 4

Nutritional value of three substrates based on group decision analytic hierarchy process of expert judgement

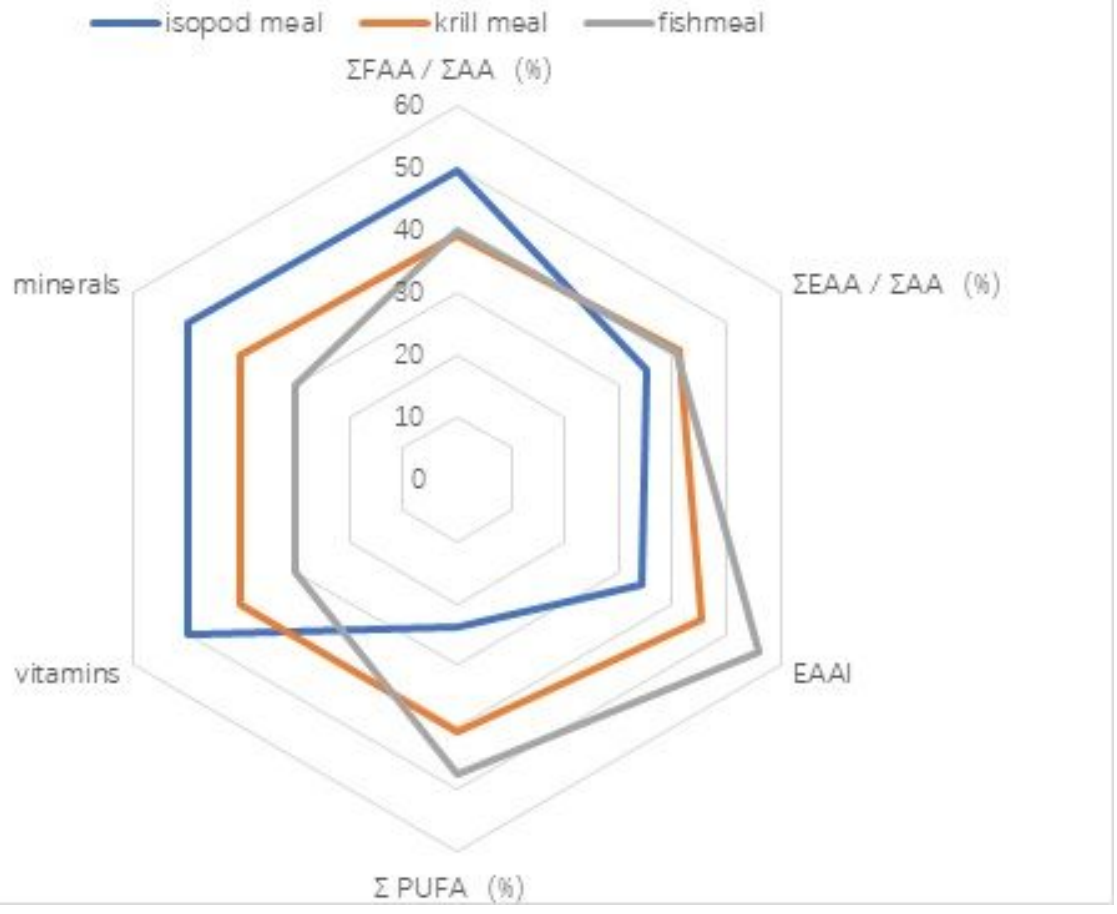

\section{Figure 5}


A radar chart illustrating the comprehensive nutritional evaluation of isopod meal, krill meal and fishmeal

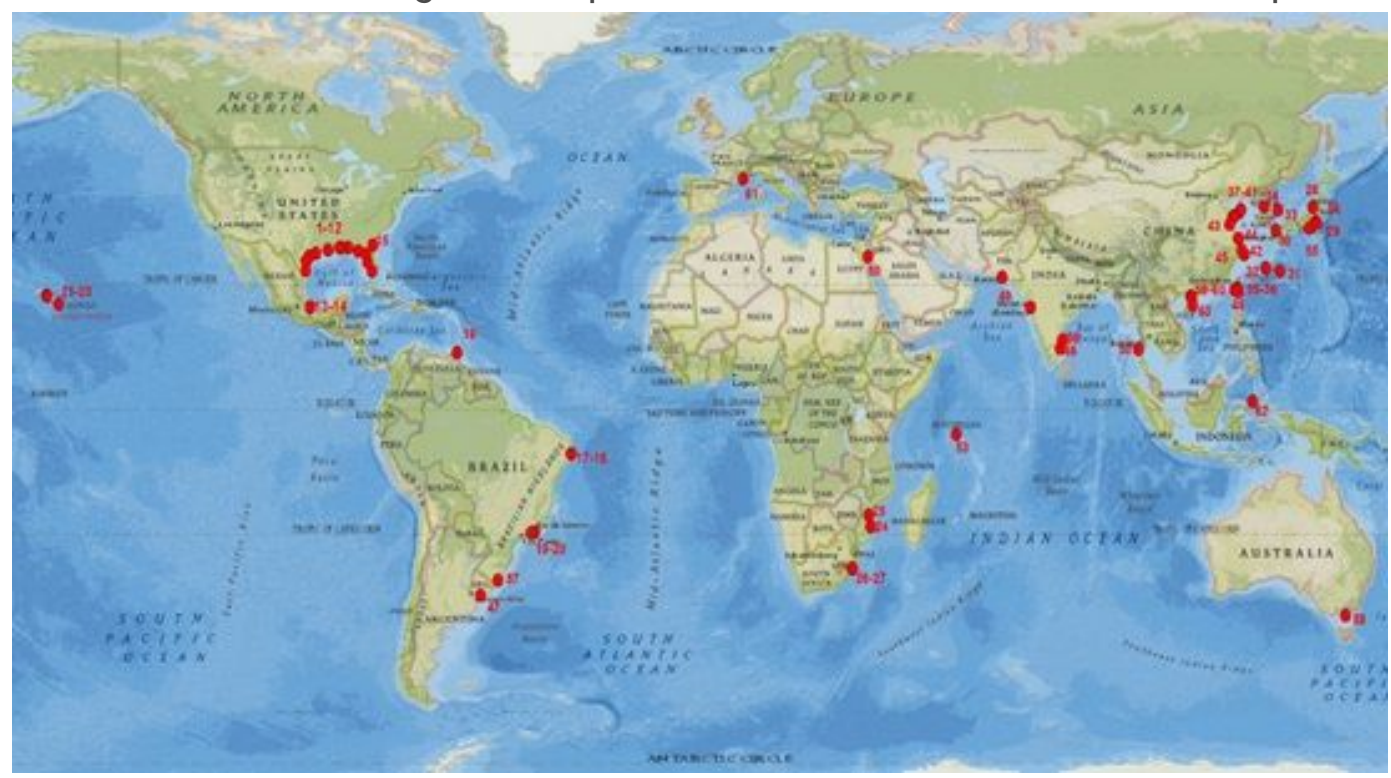

\section{Figure 6}

Currently documented global distribution of L. exotica (red dots). Mainly adapted from Hurtado et al, 2018. Map source: National Geographic World Map (ESRI). Downloaded from ArcGIS online, 2019. Sample locations were generated with ArcGIS. Version 10.5, Esri, USA from excel based on Appendix 1, Supplementary File. Note: The designations employed and the presentation of the material on this map do not imply the expression of any opinion whatsoever on the part of Research Square concerning the legal status of any country, territory, city or area or of its authorities, or concerning the delimitation of its frontiers or boundaries. This map has been provided by the authors.

\section{Supplementary Files}

This is a list of supplementary files associated with this preprint. Click to download.

- SupplementaryFileAppendix1.docx 